\title{
About requirements for diesel drives used in hard coal mine underground workings
}

\begin{abstract}
Due to the rapid increase of using transportation machines with diesel drives in hard coal mine underground workings, the technical and operational requirements for these drives are analyzed. The ambiguity of the European Union requirements regarding the emission of exhaust gases is indicated. The planned scope of work to meet the requirements given in the Diesel Engine Directive for drives intended to be installed in mobile machines operating in mine workings in atmospheres potentially threatened by methane and/or flammable dust explosion hazards is given.
\end{abstract}

Key words: mine workings, diesel drive, explosion hazard, exhaust gases, requirements regarding exhaust gases emission

\section{INTRODUCTION}

The transportation of materials and run-of-mine as well as the transportation of people all play a very important role in mining plant operation. Underground transportation systems in Polish coal mines are based on the following transportation systems:

- underground railways, used on the main transportation routes,

- suspended monorails or floor-mounted-railways in transportation between different divisions,

- conveyor belts.

An underground mining railway is the main system for the transportation of machines, equipment, materials, personnel, and waste rock. The transportation of run-of-mine in cars has been almost completely replaced by conveyor belts.

On-floor transportation has been used since the very beginning of the coal mining industry - the first rails in a coal mine appeared in the $17^{\text {th }}$ century. The beginning of suspended mine transportation dates back as far as the mid-20th century. Due to the development of cable winches in Polish mines, the use of suspended railways and then cable-driven on-floor railways became widespread.
However, they have some limitations:

- they can only move along a set route;

- the train operator has no visual contact with the transportation set,

- the possibility of the uncontrolled breaking of a cable poses a hazard,

- constant maintenance of the cable and guide rollers is needed.

The above limitations were the main reason for introducing the suspended monorails with diesel drives after 1990. Their advantages and created infrastructure (depots, fuel filling stations) contributed to the use of diesel locomotives in underground railways.

\section{REQUIREMENTS FOR DIESEL DRIVES USED IN WORKINGS WITH POTENTIALLY EXPLOSIVE ATMOSPHERES}

In accordance with the Act of April 15, 2016, on the conformity assessment and market surveillance [1], "Products placed on the market or put into service must meet the requirements". It shall be presumed that the product meets the requirements if it 
complies with the provisions of the harmonized standards with the directives. The basic directives related to diesel drives intended for use in underground workings endangered by firedamp and/or combustible dust are as follows:

- Directive 2006/42/EC of the European Parliament and of the Council of May 17, 2006, on machinery and amending Directive 95/16/EC;

- Directive 2014/34/EU of the European Parliament and of the Council of February 26, 2014, on the harmonization of the laws of the member states relating to equipment and protective systems intended for use in potentially explosive atmospheres;

- Regulation (EU) 2016/1628 of the European Parliament and of the Council of September 14, 2016, on requirements relating to gaseous and particulate pollutant emission limits and type-approval for internal combustion engines for non-road mobile machinery, amending Regulations (EU) No 1024/2012 and (EU) No 167/2013 and amending and repealing Directive 97/68/EC;

- Directive 2014/30/EU of the European Parliament and of the Council of February 26, 2014, on the harmonization of the laws of the member states relating to electromagnetic compatibility.

In Annex IV to the Machinery Directive (MD) - categories of the machines to which one of the procedure specified in Paragraph 12, Items 3 and 4 of the directive are mentioned. These are the machines intended for underground operation of the following types:

- locomotives and brake vans;

- hydraulic powered roof supports.

Regarding underground transportation machines, only locomotives for underground railways and braking trolleys for suspended monorails and floormounted railways are covered by the strictly specified procedures for conformity assessment described in the Machinery Directive.

There are the following standards harmonized with the Machinery Directive:

- PN-EN 1889-1:2011 Machines for underground mines - Mobile machines working underground Safety - Part 1: Rubber-tyred vehicles;

- PN-EN 1889-2+A1:2010 Machines for underground mines - Mobile machines working underground - Safety - Part 2: Rail locomotives;

- PN-EN 1679-1+A1:2011 Reciprocating combustion engines - Safety - Part 1: Compression ignition engines.
Most important standards harmonized with the ATEX Directive associated with the discussed problem are as follows:

- PN-EN 1834-1:2002 Reciprocating combustion engines - safety requirements for the design and construction of engines for use in potentially explosive atmospheres. Group II engines for use in flammable gas and vapour atmospheres;

- PN-EN1834-2:2002 Reciprocating combustion engines - safety requirements for the design and construction of engines for use in potentially explosive atmospheres. Group II engines for use in underground workings susceptible to firedamp and/or combustible gas.

It is worth mentioning that, in the list of Polish standards, the following standards are still in force:

- PN-G-02150:1997 Mining railway - Division and terminology;

- PN-G-36000:1997 Diesel drives for underground mine's vehicles - Requirements,

- PN-G-36001:1999 Diesel drives for underground mine's vehicles - Tests;

- PN-G-46865:2002 - Underground mine's vehicles - Diesel suspended monorail locomotives Requirements.

The standards were developed in KOMAG within the former Standardization Committee No. 148 (at present, Technical Committee No. 285 of the Polish Standardization Committee).

According to Art. 113 of the Act of June 9, 2011, "Geological and Mining Law" [2], the products are used in mining plants, which:

1) meet the requirements regarding the conformity assessment specified in the separate regulations;

2) were specified in the regulations issued on the basis of Item 15, meet the technical requirements included in those regulations referred hereinafter as "technical requirements", received approval for operation in mining plants as well as those that are marked in the way that is specified in those regulations... Thus, it should be stated that, according to the above-mentioned act, "putting into operation in the mining plant the facilities, machines, equipment, and longwalls as well as making their significant design changes or significant changes to the operational conditions requires the permission of the mining plant manager". 
It should also be mentioned that, according to the Regulation of Council of Ministers of April 30, 2004, on approval for products to be used in mining plants [3] (which is still in force), the following machines are mentioned in Annex 1:

- machines for rope transportation, suspended monorails, and their subassemblies;

- cars for personnel transportation as well as special transportation cars and vehicles with diesel drives.

These require the approval of the State Mining Authority.

\subsection{Requirements for safe operation of diesel drive in workings threatened by explosion hazard}

The PN-EN 1834-1:2002 standard includes four main configurations of diesel systems for potentially explosive atmospheres (Fig. 1). They were classified according to area from which the air is sucked and the area to which the exhaust gases are emitted.

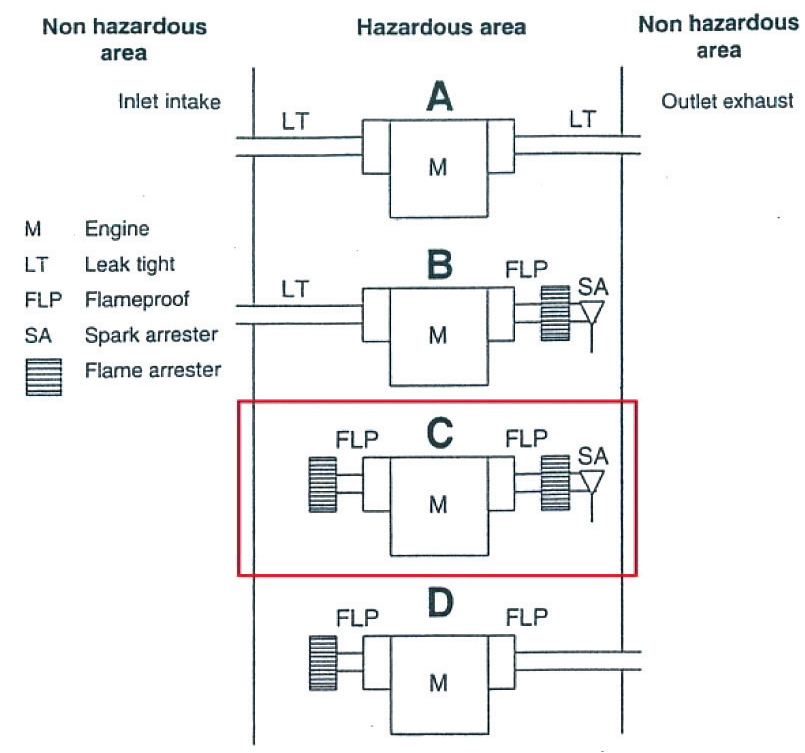

Fig. 1. Main configuration of diesel systems for potentially explosive atmospheres [4]

According to the PN-EN 1834-2:2002 standard, configuration "C" (Fig. 1) presents a diagram of a diesel drive intended for areas threatened by methane and/or flammable dust explosion hazard. In this configuration, air is sucked from and combustion products are emitted to the potentially explosive atmosphere. Air inlets and exhaust gas outlets should be protected by flame arresters, and part of the drive between them should be of anti-explosion manufacture that meets the requirements for Group I of the
PN-EN 60079-0:2013-03 standard (Explosive atmospheres - Part 0: Equipment - General Requirements).

It is necessary to equip the driving system with the automated stopping (switching off) of the diesel engine when the permissible value of rotary speed is exceeded as well as the automated stopping or self-protection of the engine should occur in the case of the following hazards [4]:

- exceeding the permissible temperature of the liquid in a diesel engine cooling system;

- insufficient pressure of lubricating oil;

- not enough liquid in the cooling system;

- exceeding the permissible temperature of the exhaust gases;

- exceeding the permissible temperature of the engine oil;

- exceeding the permissible temperature of the hydraulic oil.

Additionally, in the case of one of the above-mentioned hazards, the control system should signalize the emergency state. A fuel cut-off from the system supplying the engine should be the method for the automated stopping of the engine (both normal and emergency), and moreover, each engine should be equipped with a valve cutting off the air supply [4].

The requirements regarding the permissible temperature of the external surface of the components of the whole driving system is one of the most important conditions that are necessary to be met when diesel engines are used in mining diesel drives operated in coal mines. According to the requirements of PN-EN 1834-2:2002, the temperature of the external surfaces of all engine components and the temperature of the exhaust gases emitted to the atmosphere after the flame arrestor cannot exceed $150^{\circ} \mathrm{C}$. This refers to the operational conditions of the engine under full load [4]. The full scope of the requirements and the method for their verification are included in the PN-EN 1834-2:2002 standard as well as other related standards.

\subsection{Requirements regarding quality of exhaust gases}

The permissible emissions of toxic substances in the exhaust gases from the engines installed in machines designed for operation in mine undergrounds are given in Table 1 . They are identical to the values included in the PN-EN 1679-1+A1:2011 standard harmonized with the Machinery Directive. They refer to diesel engines featuring power from 37 to $560 \mathrm{~kW}$. 
Table 1

Emission limits of toxic substances according to PN-EN 1679-1+A1:2011[4]

\begin{tabular}{|c|c|c|c|c|}
\hline Power & $\begin{array}{c}\text { Carbon } \\
\text { monoxide } \\
\text { CO }\end{array}$ & $\begin{array}{c}\text { Hydrocarbons } \\
\text { HC }\end{array}$ & $\begin{array}{c}\text { Nitrogen } \\
\text { oxides } \\
\text { NO }_{\boldsymbol{x}}\end{array}$ & $\begin{array}{c}\text { Particulate } \\
\text { matter } \\
\mathbf{P M}\end{array}$ \\
\hline$[\mathbf{k W}]$ & {$[\mathbf{g} / \mathbf{k W h}]$} & {$[\mathbf{g} / \mathbf{k W h}]$} & {$[\mathbf{g} / \mathbf{k W h}]$} & {$[\mathbf{g} / \mathbf{k W h}]$} \\
\hline $37-75$ & 6.5 & 1.3 & 9.2 & 0.85 \\
\hline $75-130$ & 5.0 & 1.3 & 9.2 & 0.70 \\
\hline $130-560$ & 5.0 & 1.3 & 9.2 & 0.54 \\
\hline
\end{tabular}

In Table 2, the permissible emissions of toxic substances in exhaust gases specified in repealed Diesel Engine Directive (Directive No. 97/68/EC).

Transition to Stage IIIB requirements; i.e., a reduction of emissions of particulate matters (PM) by about $90 \%$ as well as a reduction of emissions of nitrogen oxides $\left(\mathrm{NO}_{x}\right)$ by $50 \%$ was the most significant change in the requirements for the emission of exhaust gases. Stage IV requirements further reduced the emissions of nitrogen oxides $\left(\mathrm{NO}_{x}\right)$ to even a level of zero. Regarding the emission of exhaust gases from non-road mobile machines, Regulation (EU) 2016/1628 of the European Parliament and of the Council of September 14, 2016, repealing the Diesel Engine Directive and introducing the Stage V requirements (Tab. 3) became in force starting on January 1, 2016. The requirements significantly reduced the level of particulate pollutants as related to the Stage IV requirements of the repealed Diesel Engine Directive.

The determination of emission limits for exhaust gases from engines intended to be installed in nonroad mobile machinery operating in a potentially

Table 2

Emission limits of toxic substances according to Diesel Engine Directive [5, 6]

\begin{tabular}{|c|c|c|c|c|c|}
\hline Power & $\begin{array}{c}\text { Date of } \\
\text { incorporation }\end{array}$ & $\begin{array}{c}\text { Carbon } \\
\text { monoxide } \\
\text { CO } \\
\end{array}$ & $\begin{array}{c}\text { Hydrocarbons } \\
\text { HC }\end{array}$ & $\begin{array}{c}\text { Nitrogen } \\
\text { oxides } \\
\text { NO }_{x} \\
\end{array}$ & $\begin{array}{c}\text { Particulate } \\
\text { matter } \\
\text { PM }\end{array}$ \\
\hline$[\mathbf{k W}]$ & - & {$[\mathbf{g} / \mathbf{k W h}]$} & {$[\mathbf{g} / \mathbf{k W h}]$} & {$[\mathbf{g} / \mathbf{k W h}]$} & [g/kWh] \\
\hline \multicolumn{6}{|c|}{ Stage I } \\
\hline $37-75$ & 04.1999 & 6.5 & 1.3 & 9.2 & 0.85 \\
\hline 75-130 & 01.1999 & 5.0 & 1.3 & 9.2 & 0.70 \\
\hline $130-560$ & 01.1999 & 5.0 & 1.3 & 9.2 & 0.54 \\
\hline \multicolumn{6}{|c|}{ Stage II } \\
\hline $19-37$ & 01.2001 & 5.5 & 1.5 & 8.0 & 0.8 \\
\hline $37-75$ & 01.2004 & 5.0 & 1.3 & 7.0 & 0.4 \\
\hline $75-130$ & 01.2003 & 5.0 & 1.0 & 6.0 & 0.3 \\
\hline $130-560$ & 01.2002 & 3.5 & 1.0 & 6.0 & 0.2 \\
\hline \multicolumn{6}{|c|}{ Stage IIIA } \\
\hline $19-37$ & 01.2007 & 5.5 & \multicolumn{2}{|c|}{$\mathrm{NO}_{x}+\mathrm{HC}-7.5$} & 0.6 \\
\hline $37-75$ & 01.2008 & 5.0 & \multicolumn{2}{|c|}{$\mathrm{NO}_{x}+\mathrm{HC}-4.7$} & 0.4 \\
\hline 75-130 & 01.2007 & 5.0 & \multicolumn{2}{|c|}{$\mathrm{NO}_{x}+\mathrm{HC}-4.0$} & 0.3 \\
\hline $130-560$ & 01.2006 & 3.5 & \multicolumn{2}{|c|}{$\mathrm{NO}_{x}+\mathrm{HC}-4.0$} & 0.2 \\
\hline \multicolumn{6}{|c|}{ Stage IIIB } \\
\hline $37-56$ & 01.2013 & 5.0 & \multicolumn{2}{|c|}{$\mathrm{NO}_{x}+\mathrm{HC}-4.7$} & 0.025 \\
\hline 56-75 & 01.2012 & 5.0 & 0.19 & 3.3 & 0.025 \\
\hline 75-130 & 01.2012 & 5.0 & 0.19 & 3.3 & 0.025 \\
\hline $130-560$ & 01.2011 & 3.5 & 0.19 & 2.0 & 0.025 \\
\hline \multicolumn{6}{|c|}{ Stage IV } \\
\hline 56-130 & 10.2014 & 3.5 & 0.19 & 0.4 & 0.025 \\
\hline $130-560$ & 01.2014 & 5.0 & 0.19 & 0.4 & 0.025 \\
\hline
\end{tabular}


explosive atmosphere in Annex VI of Regulation (EU) 2016/1628 of the European Parliament and of the Council of September 14, 2016 (Tab. 4), is an important novelty as related to the previous regulations.

Table 3

Emission limits of toxic substances according to the Regulation (EU) 2016/1628 of the European Parliament and of the Council of September 14, 2016

\begin{tabular}{|c|c|c|c|c|c|}
\hline Power & $\begin{array}{c}\text { Date } \\
\text { of } \\
\text { incorpor- } \\
\text { ation }\end{array}$ & $\begin{array}{c}\text { Carbon } \\
\text { mon- } \\
\text { oxide } \\
\text { CO }\end{array}$ & $\begin{array}{c}\text { Hydro- } \\
\text { carbons } \\
\text { HC }\end{array}$ & $\begin{array}{c}\text { Nitro- } \\
\text { gen } \\
\text { oxides } \\
\text { NO }\end{array}$ & $\begin{array}{c}\text { Parti- } \\
\text { culate } \\
\text { matter } \\
\text { PM }\end{array}$ \\
\hline$[\mathbf{k W}]$ & - & {$[\mathrm{g} / \mathbf{k W h}]$} & {$[\mathrm{g} / \mathbf{k W h}]$} & {$[\mathrm{g} / \mathbf{k W h}]$} & {$[\mathrm{g} / \mathbf{k W h}]$} \\
\hline \multicolumn{5}{|c|}{ Stage $\mathrm{V}$} \\
\hline $37-56$ & 01.2019 & 5.0 & $\mathrm{NO}_{x}+\mathrm{HC}-4.7$ & 0.015 \\
\hline $56-130$ & 01.2020 & 5.0 & 0.19 & 0.4 & 0.015 \\
\hline $130-560$ & 01.2019 & 3.5 & 0.19 & 0.4 & 0.015 \\
\hline
\end{tabular}

Source: based on data included in above-mentioned regulation

As related to the PN-EN 1679-1+A1:2011 standard, the current regulations are significantly tightened up regarding hydrocarbon $(\mathrm{HC})$ limits and especially for nitrogen oxides $\left(\mathrm{NO}_{x}\right)$ and particulate matters (PM), leaving the carbon monoxide (CO) limit at nearly the same level. From a comparison of the data given in Tables 1 and 2, it results in the fact that engines meeting the requirements of the PN-EN 1679-1+A1:2011 standard refer to those enin the repealed Diesel Engine Directive. Thus, we can see some discrepancies in the European Union requirements. In the scope of the quality of exhaust gases, new commercialized mobile machines with diesel drives intended to be used in underground workings not threatened by explosion hazard (e.g., tire vehicles) should meet the Stage V requirements given in Table 3. gines that meet the Stage I requirements included

Mobile machines (including underground locomotives for mine railways) intended to be used in atmospheres threatened by methane and/or flammable dust explosion hazard should meet the requirements given in Table 4 referring to the Stage IIIA requirements of the repealed Diesel Engine Directive. Other machines operating underground can meet the exhaust gases emission requirements given in Table 1 .

One's attention should be drawn to the Regulation of Ministry of Energy of November 23, 2016, on the detailed requirements for mine underground transportation [7] that have been in force since July 1, 2017, where the following entries are in $\$ 635$ :

1. In diesel vehicles and machines, compression-ignition engines are used.

2. The content of carbon monoxide in the gases emitted from an engine exhaust system should not be higher than the following:

- $500 \mathrm{ppm}$ - in mines not threatened by methane explosion hazard;

- 500 ppm - in mines threatened by methane explosion hazard, in the case when the methane concentration in the sucked air is $0.0 \%$;

- $1200 \mathrm{ppm}$ - in mines threatened by methane explosion hazard, in the case when the methane concentration in the sucked air is $1.0 \%$;

- 1800 ppm - in mines threatened by methane explosion hazard, in the case when the methane concentration in the sucked air is $1.5 \%$.

3. The number of diesel vehicles and machines operating at the same time in a working is set in such way as to not exceed the concentration limits of the harmful exhaust gases mentioned in $\$ 142$, Item 2 (i.e., carbon dioxide - max. 1\%; carbon monoxide - max. $0.0026 \%$; nitrogen oxides - max. $0.00026 \%$; sulphur dioxide - max. $0.000075 \%$; hydrogen sulphide - max. $0.0007 \%$; and oxygen concentration - min. 19\%).

Table 4

Emission limits of toxic substances according to the Regulation (EU) 2016/1628 of the European Parliament and of the Council of September 14, 2016, for the engines intended to be installed in non-road mobile machinery operating in potentially explosive atmospheres

\begin{tabular}{|c|c|c|c|c|c|}
\hline Power & $\begin{array}{c}\text { Date of } \\
\text { incorporation }\end{array}$ & $\begin{array}{c}\text { Carbon } \\
\text { monoxide } \\
\mathbf{C O}\end{array}$ & $\begin{array}{c}\text { Hydrocarbons } \\
\mathbf{H C}\end{array}$ & $\begin{array}{c}\text { Nitrogen } \\
\text { oxides } \\
\mathbf{N O}\end{array}$ & $\begin{array}{c}\text { Particulate } \\
\text { matter } \\
\mathbf{P M}\end{array}$ \\
\hline$[\mathbf{k W}]$ & - & {$[\mathbf{g} / \mathbf{k W h}]$} & {$[\mathbf{g} / \mathbf{k W h}]$} & {$[\mathbf{g} / \mathbf{k W h}]$} & {$[\mathbf{g} / \mathbf{k W h}]$} \\
\hline $37-56$ & 01.2017 & 5.0 & $\mathrm{NO}_{x}+\mathrm{HC}-4.7$ & 0.4 \\
\hline $56-130$ & 01.2017 & 5.0 & \multicolumn{2}{|c|}{$\mathrm{NO}_{x}+\mathrm{HC}-4.0$} & 0.3 \\
\hline $130-560$ & 01.2017 & 3.5 & \multicolumn{2}{|c|}{$\mathrm{NO}_{x}+\mathrm{HC}-4.0$} & 0.2 \\
\hline
\end{tabular}

Source: table compiled on basis of data included in above-mentioned regulation 
Thus, we can observe differences in the above-mentioned European regulations (e.g., a lack of requirements for nitrogen oxides, hydrocarbons, and particulate pollutant emission limits), and the ventilation conditions in the working are the criterial factor when deciding about the approval of using a diesel machine in a given underground working. The control requirements for diesel drives during their operation were not specified, assuming that the manufacturer of each machine determines the requirements for periodical control (the method and frequency of the control as well as the criteria for further operation) in the technical manual (technical-and-operational documentation).

\section{TECHNICAL POSSIBILITIES OF REALIZATION OF REQUIRE-MENTS FOR DIESEL DRIVES OPERATING IN WORKINGS THREATENED BY EXPLOSIVE HAZARDS}

Bearing in mind the requirements of the so-called Diesel Engine Directive, the engines' manufacturers developed adequate solutions in their products for use in non-road machinery operating on the surface. An example of a solution of one of the manufacturers is given in Table 5.

Table 5

Development of diesel engine solutions for non-road vehicles [8]

\begin{tabular}{|c|c|c|}
\hline Stage & Diagram & Description \\
\hline I & two-valve head & $\begin{array}{l}\text { Presented system is simplest solution with } \\
\text { mechanically controlled inline diesel injec- } \\
\text { tion pump and distributor diesel injection } \\
\text { pump [9]. Engine is equipped with two-valve } \\
\text { head, typical turbocharger with fixed geo- } \\
\text { metry of guide's blades, simple intake system } \\
\text { with air filter, and exhaust system. }\end{array}$ \\
\hline II & $\begin{array}{l}\text { two-valve head } \\
\text { or } \\
\text { four-valve head }\end{array}$ & $\begin{array}{l}\text { Equipping engine with high-pressure fuel } \\
\text { feeding system (e.g., electronically controlled } \\
\text { common rail [9], two- or four-valve cylinder } \\
\text { head, and cooler of compressed air intake [so- } \\
\text { called intercooler] is improving modification } \\
\text { of previous system. Engine is usually fitted } \\
\text { with turbocharger of guide's blade fixed geo- } \\
\text { metry. Use of intercooler allows for increas- } \\
\text { ing engine power, while electronically con- } \\
\text { trolled fuel injection system decreases emis- } \\
\text { sion of hazardous substances with exhaust } \\
\text { gases. }\end{array}$ \\
\hline IIIA & four-valve head & $\begin{array}{l}\text { Another step, is use of EGR system with its } \\
\text { own cooler and turbocharger of blade variable } \\
\text { geometry. Use of cooled stream of exhaust } \\
\text { gases lowers temperature of combustion pro- } \\
\text { cess, limiting emission of nitrogen oxides } \\
\left(\mathrm{NO}_{x}\right) \text {. Turbocharger of variable guide's blade } \\
\text { geometry improves engine operational cha- } \\
\text { racteristics (e.g., reduces so-called turbo lag } \\
\text { effect at low outlet speed of exhaust gases). }\end{array}$ \\
\hline
\end{tabular}


Table 5 cont.

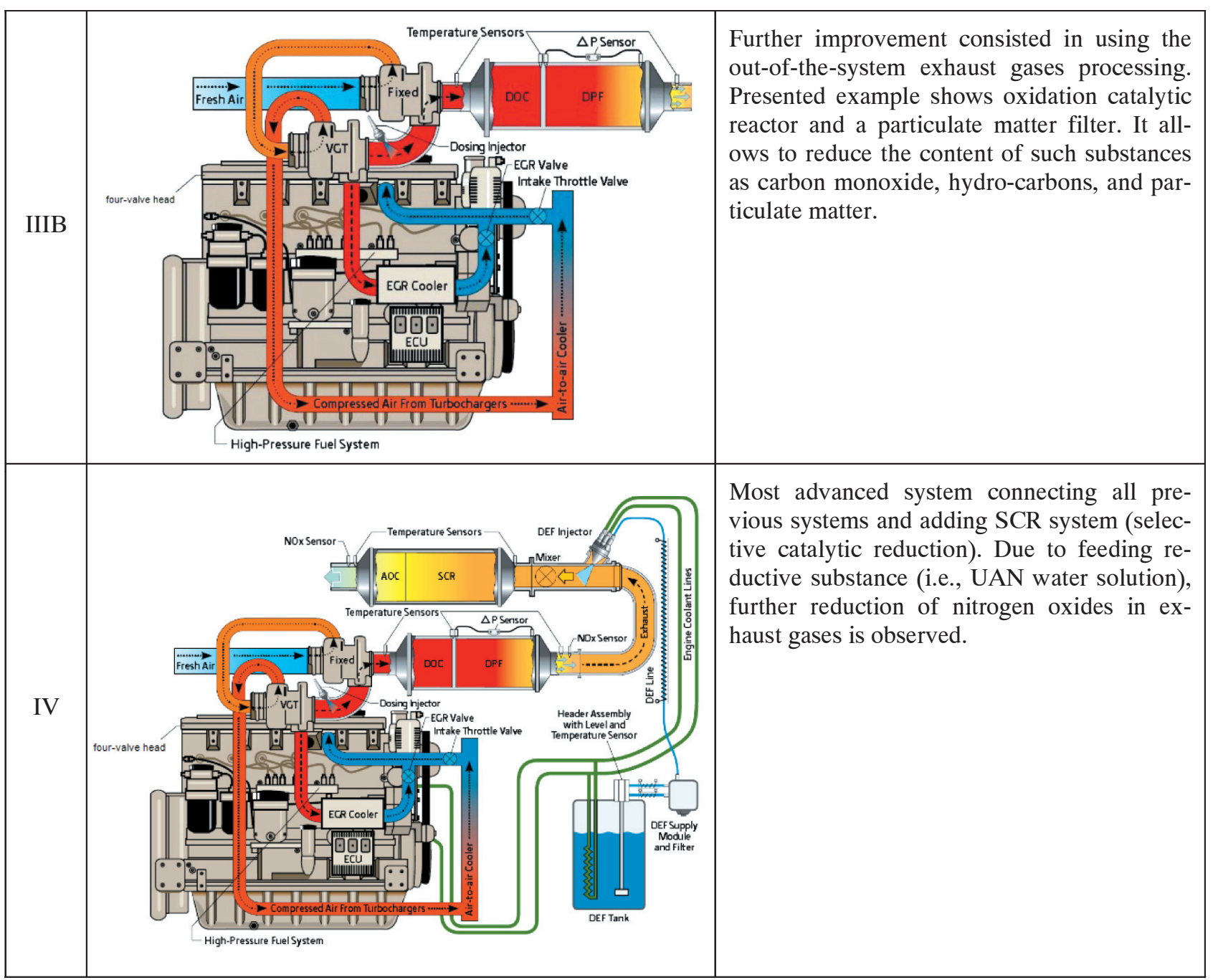

Basing on information included in Table 5, we can conclude that:

- the requirements for exhaust gases quality at Stages I, II, and IIIA were met due to the improvement of the engine feeding system, especially the control of the time and number of fuel injection stages;

- the emission level of each substance according to the requirements of Stages IIIB and IV can be satisfied only by using the so-called off exhaust gases processing system (consisting of a catalytic reactor, particulate matter filter, and other components).

It should be mentioned that none of the diesel engine manufacturers adapts the already-made engines for operation in underground workings threatened by methane and/or flammable dust explosion hazard, leaving the problem to be solved by the manufactur- ers of underground mining machines with diesel drives.

A sample design of the anti-explosion manufacture of a diesel drive system for transportation machines used in underground workings threatened by methane and/or flammable dust explosion hazards is presented in Figure 2.

The engine was equipped with a liquid-cooled exhaust manifold and turbocharger as well as an exhaust gases outlet hose with a water jacket. In place of an exhaust gas water washer, a "dry" heat exchanger can be used. In the case of a water washer, the exhaust gases flow through its chambers and are cooled down by contacting the cooling water, and the soot is washed out. Periodic replacement of the water is required (after each working shift). The evaporation of water and its frequent splashing out have an adverse impact during operation. In a "dry" heat exchanger, exhaust gases do not directly contact the cooling water, so the soot is not removed from the exhaust gases 
An additional water cooling system is requited (pump, cooler). Electronic supervising systems controlling the parameters deciding about safe operation are installed. In Figure 3, a sample design of a diesel engine meeting the Stage I requirements equipped with a water system cooling the turbocharger and an outlet exhaust gases collector is shown.

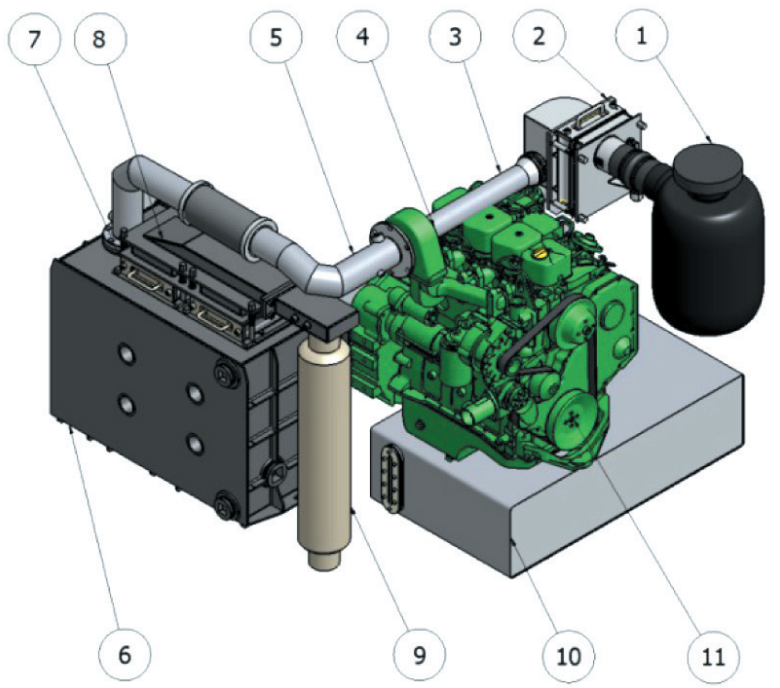

Fig. 2. Sample design of engine unit intended to operate in atmosphere threatened by methane and/or flammable dust explosion hazard meeting Stage I/II requirements: 1 - air filter, 2 - flame arrester in inlet system, 3 - inlet hose, 4 - turbocharger, 5 - exhaust gases outlet hose, 6 - water exhaust gases washer, 7 - flame arrester in exhaust system, 8 - exhaust manifold, 9 - spark arrester, 10 - fuel tank, 11 - diesel engine [5]

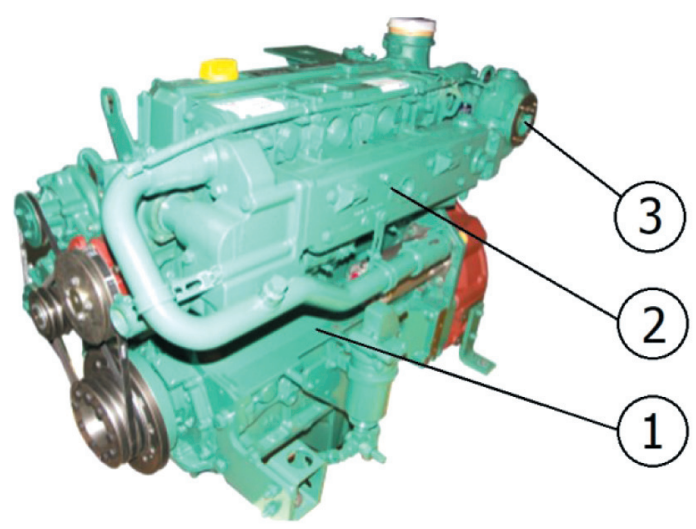

Fig. 3. Sample design of engine unit intended to operate in atmosphere threatened by methane and/or flammable dust explosion hazard meeting Stage I/II requirements: 1 - diesel engine, 2 - liquid-cooled outlet exhaust gases collector, 3 - liquid-cooled turbocharger [5]

The diesel engines used so far by the Polish manufacturers of transportation machines to be used in underground workings threatened by methane and/or flammable gas explosion hazards meet the requirements of the Diesel Engine Directive - Stage II, and incidentally Stage IIIA. The use of engines meeting current requirements needs further research work. A testing infrastructure, an experienced staff, and testing facilities enable us to conduct such research work at KOMAG. Figure 4 shows a sample design of an industrial diesel engine meeting Stage IV/V requirements.

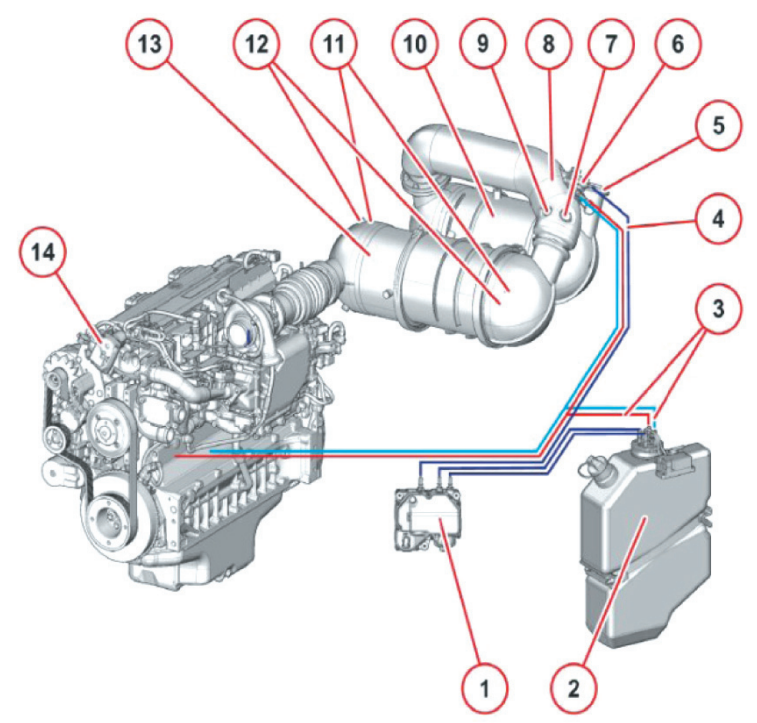

Fig. 4. Sample design of industrial diesel engine meeting Stage IV/V requirements: 1 - SCR supply pump, 2-SCR tank, 3 - coolant line for preheating SCR tank for cooling metering unit, 4 - SCR hose, 5 - NO ${ }_{x}$ sensor, 6 - metering unit, 7 - NO $O_{x}$ sensor, 8 - temperature sensor, 9 - pressure sensor, 10 - SCR catalytic reactor, 11 - differential pressure sensor, 12 - temperature sensor, 13 - diesel particle filter (DPF) for diesel engines, 14 - throttle valve [11]

The adaptation of engines for operations in areas threatened by methane and/or flammable dust explosion hazards according to the requirements of the ATEX Directive as well as the Diesel Engine Directive include the following [10]:

- protection of exhaust gases collector and turbocharged surfaces against excessive temperatures,

- anti-explosion protection of intake-outtake system of flame arrester,

- anti-explosion protection of engine's electrical equipment - injectors, sensors, engine controller, alternator, and starter.

The adaptation of a factory-made engine meeting Stage IIIA level requirements requires the design of a diesel drive for operation in areas threatened by methane and/or flammable dust explosion hazards 
and requires undergoing research and development work related to the following:

- development of water-cooled outtake exhaust gases collector and turbocharger in anti-explosion (flameproof) manufacture,

- adapting the existing control system (controller, sensors) to explosive atmospheres.

It is essential to adapt the injectors to operate in a potentially explosive atmosphere. Due to the need for the precise positioning of the injectors in pockets, stable fixation, and high operating temperature, their adaptation to meet the ATEX Directive requirements is a complex technological issue. Close cooperation with the engine's supplier is necessary.

\section{SUMMARY}

The transportation of materials and run-of mine as well as the transportation of personnel are important parts of the mining processes. In the beginning of the 1990s, trains with diesel drives started to be used in place of the widely used cable driven transportation machines in coal mines due to the latter's limitations. The created infrastructure (depots, refueling chambers) contributed to the use of underground diesel locomotives. The implemented diesel drives should meet the safe operation requirements in workings threatened by explosion hazards as well as EU exhaust gases quality requirements. Discrepancies in these requirements were indicated. The standards harmonized with the Machinery Directive indicate that rubber-tired vehicles as well as mobile machines (including underground locomotives) are intended for use in atmospheres potentially threatened by methane and/or flammable dust explosion hazards need to meet the much more restrictive requirements of Regulation (EU) 2016/1628 of the European Parliament and of the Council of September 14, 2016 (Stage V and Stage IIIA) than the requirements for other machines, included in PN-EN 1679-1+A1:2011 standard.

Engine manufacturers offer engine designs meeting Stage $\mathrm{V}$ exhaust gases emission regulations for non-road vehicles but do not offer engines for mobile machines intended for use in atmospheres potentially threatened by methane and/or flammable dust explosion hazards. To adapt the engine to the requirements of the ATEX Directive, it is necessary to conduct $\mathrm{R} \& \mathrm{D}$ work, including the following:

- protection against excessive surface temperature of outlet exhaust gases collector and turbocharger,

- anti-explosion protection of intake-outtake flame arrester system,

- anti-explosion protection of engine's electrical equipment - injectors, sensors, engine controller, alternator, and starter.

The above-mentioned work can be realized by KOMAG in close cooperation with the engine manufacturer.

\section{References}

[1] Ustawa z dnia 15 kwietnia 2016 r. o systemach oceny zgodności i nadzoru rynku, Dz.U. 2016, poz. 542 z późn. zm.

[2] Ustawa z dnia 9 czerwca 2011 r. - Prawo geologiczne i górnicze, Dz.U. 2011, nr 163, poz. 981 z późn. zm., tekst jednolity Dz.U. 2017, poz. 2126, stan prawny na 12.10 .2017 r.

[3] Rozporządzenie Rady Ministrów z dnia 30 kwietnia 2004 r. $w$ sprawie dopuszczania wyrobów do stosowania $w$ zakładach górniczych, Dz.U. 2004, nr 99, poz. 1003 z późn. zm.

[4] Brzeżański M., Pieczora E., Kaczmarczyk K.: Rozwiązania napędów spalinowych do zastosowań $w$ wyrobiskach podziemnych węla kamiennego, "Silniki Spalinowe" 2010, 3: 28-40.

[5] Dobrzaniecki P., Majewski M., Kaczmarczyk K., Suffner H.: Nowoczesny napęd spalinowy maszyn samobieżnych dla górnictwa. Identyfikacja zagadnień $i$ zakresu prac zwiazanych $z$ dostosowaniem silnika spalinowego do wymagań Etapu IV dyrektywy spalinowej, ITG KOMAG, Gliwice 2016 [unpublished].

[6] Pieczora E., Suffner H.: Rozwój napędów dołowych kolejek podwieszonych, "Maszyny Górnicze" 2017, 3: 44-57.

[7] Rozporzadzenie Ministra Energii z dnia 23 listopada 2016 r. w sprawie szczegółowych wymagań dotyczacych prowadzenia ruchu podziemnych zakładów górniczych, Dz.U. 2017, poz. 1118.

[8] Informational materials of John Deere Company, www.deere.pl, 2017.

[9] Dobrzaniecki P., Kaczmarczyk K.: Układy zasilania silników spalinowych eksploatowanych $w$ kopalniach wegla kamiennego na przykładzie rozwiązań ITG KOMAG, "Maszyny Górnicze" 2017, 1: 63-76.

[10] Dobrzaniecki P.: Dostosowanie silnika spalinowego z uktadem wtryskowym common rail górniczej maszyny roboczej do obowiąujących wymagań i przepisów, "Maszyny Górnicze" 2016, 3: 45-53.

[11] Informational materials of Deutz, 2017 [delivered by Biuro Techniczno-Handlowe FAST].

EDWARD PIECZORA, Ph.D., Eng. PIOTR DOBRZANIECKI, Ph.D., Eng. KOMAG Institute of Mining Technology ul. Pszczyńska 37, 44-101 Gliwice \{epieczora,pdobrzaniecki\}@komag.eu 


\title{
O wymaganiach dla napędów spalinowych do podziemnych wyrobisk kopalń węgla kamiennego
}

\begin{abstract}
Majac na uwadze ciagly wzrost zastosowań urzadzeń transportowych z napędem spalinowym w podziemiach kopalń wegla kamiennego, dokonano analizy wymagań technicznych i eksploatacyjnych ww. napędu. Wskazano na niejednoznaczność obowiązujacych unijnych wymagań $w$ zakresie emisji spalin. Przedstawiono zakres prac, jakie należy podjać $w$ celu spetnienia wymagań określonych $w$ dyrektywie spalinowej dla napędów przeznaczonych do maszyn mobilnych eksploatowanych $w$ wyrobiskach potencjalnie zagrożonych wybuchem metanu i/lub palnego pytu.
\end{abstract}

Słowa kluczowe: wyrobiska górnicze, napęd spalinowy, zagrożenie wybuchem, spaliny, wymagania odnośnie do emisji spalin

\section{WSTĘP}

Transport materiałów i urobku oraz przewóz ludzi jest jednym $z$ najważniejszych ogniw procesu wydobywczego zakładu górniczego. W polskich kopalniach węgla kamiennego systemy transportu podziemnego bazują na:

- kopalnianych kolejach podziemnych, stosowanych na głównych drogach transportowych,

- kolejach podwieszonych lub spągowych w transporcie oddziałowym,

- przenośnikach taśmowych.

Kopalniana kolej podziemna stanowi podstawowy system transportu maszyn, urządzeń i materiałów, przewozu ludzi oraz transportu (odstawy) skały płonnej. Transport urobku wozami został praktycznie w całości zastąpiony odstawą przenośnikami taśmowymi.

Transport po spągu jest stosowany od początku rozwoju górnictwa - pierwsze tory kopalniane pojawiły się w XVII wieku. Dopiero w połowie XX wieku zaczęto stosować transport podwieszony. W wyniku rozwoju kołowrotów linowych w polskich kopalniach szybko upowszechniły się szynowe kolejki podwieszone, a następnie spągowe $\mathrm{z}$ napędem linowym.
Posiadają one jednak ograniczenia, tj:

- możliwość prowadzenia transportu jedynie wzdłuż z góry wyznaczonej trasy,

- brak wizualnego kontaktu pracownika obsługującego napęd z zestawem transportowym,

- możliwość niekontrolowanego zerwania liny ciągnącej i stwarzającej zagrożenie wypadkowe,

- konieczne, stałe nakłady na konserwację liny oraz zespołów rolek prowadzących.

Wyżej wymienione ograniczenia stanowiły podstawę wprowadzenia do eksploatacji, po 1990 roku, kolejek podwieszonych z napędem spalinowym. Ich zalety oraz powstała infrastruktura (zajezdnie, komory tankowania paliw) stanowiły przyczynek zastosowania lokomotyw spalinowych do kopalnianej kolei podziemnej.

\section{WYMAGANIA DLA NAPĘDÓW SPALINOWYCH EKSPLOATOWANYCH W WYROBISKACH POTENCJALNIE ZAGROŻONYCH WYBUCHEM}

Zgodnie z Ustawa z dnia 15 kwietnia 2016 r. o systemach oceny zgodności i nadzoru rynku [1], „Wyroby wprowadzane do obrotu lub oddawane do użytku muszą spełniać wymagania”. Domniemywa się, że 
wyrób spełnia wymagania, jeżeli jest zgodny z postanowieniami norm zharmonizowanych $\mathrm{z}$ określonymi dyrektywami. Podstawowe dyrektywy związane z napędami spalinowymi przeznaczonymi do stosowania w podziemnych wyrobiskach zagrożonych wybuchem metanu i/lub palnego pyłu to:

- Dyrektywa 2006/42/WE Parlamentu Europejskiego i Rady z dnia 17 maja 2006 r. w sprawie maszyn, zmieniająca dyrektywę 95/16/WE (tzw. dyrektywa maszynowa MD),

- Dyrektywa Parlamentu Europejskiego i Rady 2014/34/UE z dnia 26 lutego 2014 r. w sprawie harmonizacji ustawodawstw państw członkowskich odnoszących się do urządzeń i systemów ochronnych przeznaczonych do użytku w atmosferze potencjalnie wybuchowej (tzw. dyrektywa ATEX),

- Rozporządzenie Parlamentu Europejskiego i Rady (UE) 2016/1628 z dnia 14 września 2016 r. zmieniające i uchylające Dyrektywę 97/68/WE Parlamentu Europejskiego i Rady w sprawie zbliżenia ustawodawstw państw członkowskich odnoszących się do środków dotyczących graniczenia emisji zanieczyszczeń gazowych i pyłowych z silników spalinowych montowanych w maszynach samojezdnych nieporuszających się po drogach (tzw. dyrektywa spalinowa),

- Dyrektywa Parlamentu Europejskiego i Rady 2014/30/UE z dnia 26 lutego 2014 r. w sprawie harmonizacji ustawodawstw państw członkowskich odnoszących się do kompatybilności elektromagnetycznej (tzw. dyrektywa EMC).

W załączniku IV dyrektywy maszynowej (MD) wymieniono kategorie maszyn, do których ma zastosowanie jedna $\mathrm{z}$ procedur określonych $\mathrm{w}$ art. 12 ust. 3 i 4 dyrektywy. Są to m.in. maszyny do robót podziemnych następujących rodzajów:

- lokomotywy i wózki hamulcowe,

- hydrauliczne obudowy zmechanizowane.

W zakresie dołowych urządzeń transportowych tylko lokomotywy do kopalnianej kolei podziemnej oraz wózki hamulcowe do kolejek podwieszonych i spągowych zostały zatem objęte ściśle określonymi procedurami oceny zgodności opisanymi w dyrektywie maszynowej.

Normami zharmonizowanymi z dyrektywą maszynową są m.in.:

- PN-EN 1889-1:2011: Maszyny dla górnictwa podziemnego - Podziemne maszyny samobieżne - Bezpieczeństwo - Część 1: Pojazdy oponowe,
- PN-EN 1889-2+A1:2010: Maszyny dla górnictwa podziemnego - Podziemne maszyny samobieżne Bezpieczeństwo - Część 2: Lokomotywy szynowe,

- PN-EN 1679-1+A1:2011: Silniki spalinowe ttokowe - Bezpieczeństwo - Część 1: Silniki o zaptonie samoczynnym.

Najważniejsze normy zharmonizowane $\mathrm{z}$ dyrektywą ATEX związane z przedmiotową tematyką to:

- PN-EN 1834-1:2002: Silniki spalinowe tlokowe Wymagania bezpieczeństwa dotyczace projektowania i budowy silników przeznaczonych do stosowania $w$ przestrzeniach zagrożonych wybuchem Część 1: Silniki grupy II przeznaczone do stosowania $w$ atmosferze palnych gazów i par,

- PN-EN 1834-2:2002: Silniki spalinowe ttokowe Wymagania bezpieczeństwa dotyczace projektowania i budowy silników przeznaczonych do stosowania $w$ przestrzeniach zagrożonych wybuchem Część 2: Silniki grupy I przeznaczone do stosowania $w$ pracach podziemnych zagrożonych występowaniem metanu i/lub palnego pytu.

Warto również wspomnieć, że w wykazie polskich norm nadal znajdują się (jako aktualne) m.in. następujące normy:

- PN-G-02150:1997: Kopalniane koleje szynowe Podziat i terminologia,

- PN-G-36000:1997: Napędy spalinowe dla podziemnych pojazdów górniczych - Wymagania,

- PN-G-36001:1999: Napędy spalinowe dla podziemnych pojazdów górniczych - Badania,

- PN-G-46865:2002: Lokomotywy kopalniane podziemne - Lokomotywy podwieszone spalinowe Wymagania.

Normy te opracowano w KOMAG-u w ramach byłej Normalizacyjnej Komisji Problemowej nr 148 (obecnie Komitet Techniczny nr 285) Polskiego Komitetu Normalizacyjnego.

Zgodnie z art. 113 Ustawy z dnia 9 czerwca $2011 \mathrm{r}$ - Prawo geologiczne i górnicze [2] w ruchu zakładu górniczego stosuje się wyroby, które: „spełniają wymagania dotyczące oceny zgodności, określone w odrębnych przepisach lub zostały określone w przepisach wydanych na podstawie ust. 15 , spełniają wymagania techniczne określone w tych przepisach, zwane dalej „wymaganiami technicznymi”, zostały dopuszczone do stosowania w zakładach górniczych oraz oznakowane w sposób określony w tych przepisach...”. Należy zatem mieć na uwadze, że zgodnie w ww. ustawą 
„oddanie do ruchu w zakładzie górniczym obiektów, maszyn, urządzeń i ścian, jak również dokonywanie ich istotnych zmian konstrukcyjnych lub istotnych zmian warunków eksploatacji, wymaga zezwolenia kierownika ruchu zakładu górniczego".

Nie wolno przy tym zapominać, że zgodnie z nadal obowiązującym Rozporządzeniem Rady Ministrów z dnia 30 kwietnia 2004 r. w sprawie dopuszczania wyrobów do stosowania $w$ zakładach górniczych [3] wymienione w jego załączniku 1 :

- urządzenia transportu linowego, kolejki podwieszone, kolejki spągowe oraz ich podzespoły,

- wozy do przewozu osób i wozy specjalne oraz pojazdy z napędem spalinowym do przewozu osób, wymagają dopuszczenia Prezesa Wyższego Urzędu Górniczego.

\subsection{Wymagania dotyczące bezpiecznej eksploatacji napędu spalinowego w wyrobiskach zagrożonych wybuchem}

PN-EN 1834-1:2002 zawiera cztery podstawowe konfiguracje układów spalinowych do stref zagrożonych atmosferą wybuchową (rys. 1). Sklasyfikowano je ze względu na przestrzeń, z której powietrze jest zasysane, oraz przestrzeń, do której emitowane są spaliny.

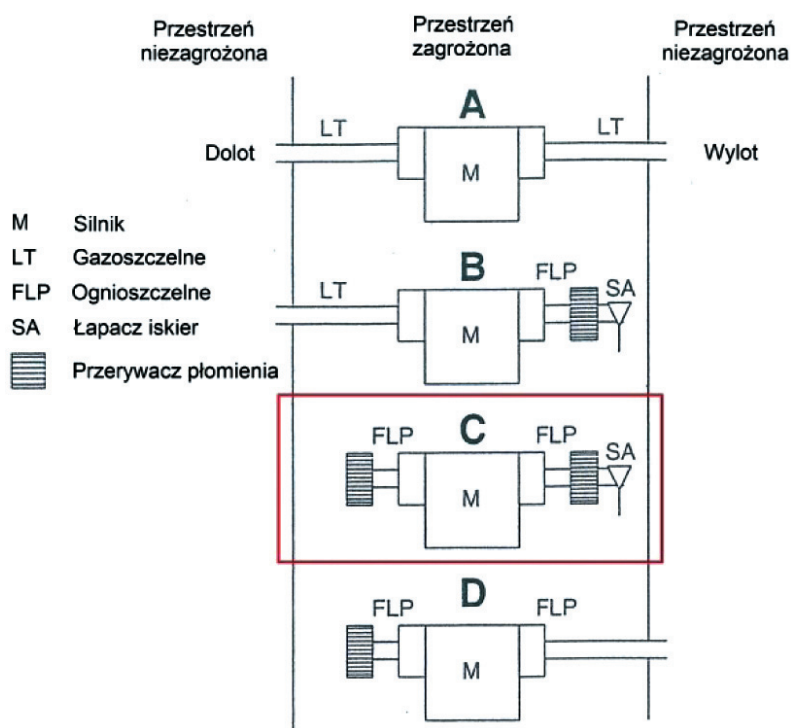

Rys. 1. Podstawowe konfiguracje układów spalinowych do stref zagrożonych atmosfera wybuchowa [4]

Zgodnie z PN-EN 1834-2:2002 konfiguracja "C” (rys. 1) przedstawia schemat napędu spalinowego przeznaczonego do stref zagrożonych wybuchem metanu i/lub palnego pyłu. W tej konfiguracji zarówno powietrze do procesu spalania, jak i produkty spalania zasysane są z przestrzeni potencjalnie zagrożonej wybuchem i do niej emitowane. Dolot powietrza i wylot spalin muszą być zatem zabezpieczone przery- waczami płomieni, a zawarta pomiędzy nimi część napędu musi być budowy przeciwwybuchowej, spełniającej wymagania dla grupy I PN-EN 60079-0:2013-03 (Atmosfery wybuchowe - Część 0: Urządzenia - Podstawowe wymagania).

Konieczne jest również wyposażenie układu napędowego w system samoczynnego (automatycznego) zatrzymania (wyłączenia) silnika spalinowego, po przekroczeniu nadmiernej prędkości obrotowej, a także realizujący samoczynne zatrzymanie lub samoczynne zabezpieczenie silnika, w przypadku następujących stanów zagrożenia [4]:

- przekroczenie dopuszczalnej temperatury cieczy w układzie chłodzenia silnika spalinowego,

- niedostateczna wartość ciśnienia oleju smarującego,

- zbyt mała ilość cieczy w układzie chłodzenia,

- przekroczenie dopuszczalnej temperatury spalin,

- przekroczenie dopuszczalnej temperatury oleju silnikowego,

- przekroczenie dopuszczalnej temperatury oleju hydraulicznego.

Dodatkowo, w przypadku wystąpienia jednego z wymienionych zagrożeń układ kontroli powinien sygnalizować je jako stan alarmowy. Zarówno normalnym, jak i awaryjnym sposobem samoczynnego zatrzymywania silnika powinno być odcięcie dopływu paliwa do układu zasilającego silnik. Ponadto każdy silnik powinien być wyposażony w zawór odcinający dopływ powietrza [4].

Jednym z najważniejszych warunków, koniecznych do spełnienia, przy zastosowaniu silników spalinowych do górniczych napędów spalinowych, eksploatowanych w kopalniach węgla, są wymagania dotyczące dopuszczalnej temperatury zewnętrznej powierzchni elementów całego układu napędowego. Zgodnie z normą PN-EN 1834-2:2002, temperatura powierzchni zewnętrznych wszystkich elementów silnika oraz temperatura spalin emitowanych do atmosfery bezpośrednio za przerywaczem płomieni nie może przekraczać wartości $150^{\circ} \mathrm{C}$. Dotyczy to warunków pracy silnika pod pełnym obciążeniem [4]. Pełny zakres wymagań oraz sposób ich weryfikacji zawarto w normie PN-EN 1834-2:2002 i normach z nią związanych.

\subsection{Wymagania dotyczące jakości spalin}

Dopuszczalne emisje substancji toksycznych w spalinach silników instalowanych $\mathrm{w}$ maszynach przeznaczonych do pracy pod ziemią podano w tabeli 1 . Są one zgodne $\mathrm{z}$ wartościami zawartymi w normie PN-EN1679-1+A1:2011, zharmonizowanej z dyrektywą maszynową. Dotyczą one silników spalinowych o mocy od $37 \mathrm{~kW}$ do $560 \mathrm{~kW}$. 
Tabela 1

Dopuszczalne emisje substancji toksycznych według PN-EN 1679-1+A1:2011[4]

\begin{tabular}{|c|c|c|c|c|}
\hline Moc & $\begin{array}{c}\text { Tlenek } \\
\text { węgla } \\
\mathbf{C O}\end{array}$ & $\begin{array}{c}\text { Węglowodory } \\
\text { HC }\end{array}$ & $\begin{array}{c}\text { Tlenki } \\
\text { azotu } \\
\mathbf{N O}_{\boldsymbol{x}}\end{array}$ & $\begin{array}{c}\text { Cząstki } \\
\text { stałe } \\
\mathbf{P M}\end{array}$ \\
\hline$[\mathbf{k W}]$ & {$[\mathbf{g} / \mathbf{k W h}]$} & {$[\mathbf{g} / \mathbf{k W h}]$} & {$[\mathbf{g} / \mathbf{k W h}]$} & {$[\mathbf{g} / \mathbf{k W h}]$} \\
\hline $37-75$ & 6,5 & 1,3 & 9,2 & 0,85 \\
\hline $75-130$ & 5,0 & 1,3 & 9,2 & 0,70 \\
\hline $130-560$ & 5,0 & 1,3 & 9,2 & 0,54 \\
\hline
\end{tabular}

W tabeli 2 podano dopuszczalne emisje substancji toksycznych w spalinach określone w uchylonej dyrektywie spalinowej (Dyrektywa 97/68/WE).

Najbardziej znaczącą zmianą, w wymaganiach emisji spalin, było przejście do wymagań etapu IIIB, tj. zmniejszenie emisji masowej cząstek stałych (PM) o ok. $90 \%$ oraz ok. $50 \%$ zmniejszenie emisji tlenków azotu $\left(\mathrm{NO}_{x}\right)$. W etapie IV jeszcze bardziej obniżono wymagania odnośnie do poziomu emisji tlenków azotu $\left(\mathrm{NO}_{x}\right)$. W zakresie emisji spalin dla pojazdów niedrogowych od 1 stycznia 2017 roku obowiązuje Rozporzadzenie Parlamentu Europejskiego i Rady (UE) 2016/1628 z dnia 14 września 2016 r. uchylające dyrektywę spalinową i wprowadzające wymagania etapu V (tab. 3). Wymagania te znacząco obniżyły poziom emisji cząstek stałych w stosunku do wymagań etapu IV uchylonej dyrektywy spalinowej.

Istotną nowością, w stosunku do poprzednio obowiązujących przepisów, jest określenie w załączniku VI Rozporzadzenia Parlamentu Europejskiego i Rady (UE) 2016/1628 z dnia 14 września 2016 r. w sprawie wymogów dotyczących wartości granicznych emisji zanieczyszczeń gazowych $i$ pyłowych oraz homologacji typu w odniesieniu do silników spalinowych wewnętrznego spalania przeznaczonych do maszyn mobilnych nieporuszających się po drogach wymagań dotyczących emisji spalin dla silników przeznaczonych do montażu w maszynie mobilnej nieporuszającej się po drogach, która ma być użytkowana w atmosferze potencjalnie wybuchowej (tab. 4).

Tabela 2

Dopuszczalne emisje substancji toksycznych według dyrektywy spalinowej [5, 6]

\begin{tabular}{|c|c|c|c|c|c|}
\hline Moc & $\begin{array}{c}\text { Data } \\
\text { wprowadzenia }\end{array}$ & $\begin{array}{c}\text { Tlenek } \\
\text { węgla } \\
\text { CO }\end{array}$ & $\begin{array}{c}\text { Węglowodory } \\
\text { HC }\end{array}$ & $\begin{array}{c}\text { Tlenki } \\
\text { azotu } \\
\text { NO }_{x}\end{array}$ & $\begin{array}{c}\text { Cząstki } \\
\text { stałe } \\
\text { PM }\end{array}$ \\
\hline$[\mathrm{kW}]$ & - & [g/kWh] & [g/kWh] & {$[\mathrm{g} / \mathbf{k W h}]$} & [g/kWh] \\
\hline \multicolumn{6}{|c|}{ Etap I } \\
\hline $37-75$ & 04.1999 & 6,5 & 1,3 & 9,2 & 0,85 \\
\hline $75-130$ & 01.1999 & 5,0 & 1,3 & 9,2 & 0,70 \\
\hline $130-560$ & 01.1999 & 5,0 & 1,3 & 9,2 & 0,54 \\
\hline \multicolumn{6}{|c|}{ Etap II } \\
\hline $19 \div 37$ & 01.2001 & 5,5 & 1,5 & 8,0 & 0,8 \\
\hline $37-75$ & 01.2004 & 5,0 & 1,3 & 7,0 & 0,4 \\
\hline $75-130$ & 01.2003 & 5,0 & 1,0 & 6,0 & 0,3 \\
\hline $130-560$ & 01.2002 & 3,5 & 1,0 & 6,0 & 0,2 \\
\hline \multicolumn{6}{|c|}{ Etap IIIA } \\
\hline $19-37$ & 01.2007 & 5,5 & \multicolumn{2}{|c|}{$\mathrm{NO}_{x}+\mathrm{HC}-7,5$} & 0,6 \\
\hline $37-75$ & 01.2008 & 5,0 & \multicolumn{2}{|c|}{$\mathrm{NO}_{x}+\mathrm{HC}-4,7$} & 0,4 \\
\hline $75-130$ & 01.2007 & 5,0 & \multicolumn{2}{|c|}{$\mathrm{NO}_{x}+\mathrm{HC}-4,0$} & 0,3 \\
\hline $130-560$ & 01.2006 & 3,5 & \multicolumn{2}{|c|}{$\mathrm{NO}_{x}+\mathrm{HC}-4,0$} & 0,2 \\
\hline \multicolumn{6}{|c|}{ Etap IIIB } \\
\hline $37-56$ & 01.2013 & 5,0 & \multicolumn{2}{|c|}{$\mathrm{NO}_{x}+\mathrm{HC}-4,7$} & 0,025 \\
\hline $56-75$ & 01.2012 & 5,0 & 0,19 & 3,3 & 0,025 \\
\hline 75-130 & 01.2012 & 5,0 & 0,19 & 3,3 & 0,025 \\
\hline $130-560$ & 01.2011 & 3,5 & 0,19 & 2,0 & 0,025 \\
\hline \multicolumn{6}{|c|}{ Etap IV } \\
\hline 56-130 & 10.2014 & 3,5 & 0,19 & 0,4 & 0,025 \\
\hline $130-560$ & 01.2014 & 5,0 & 0,19 & 0,4 & 0,025 \\
\hline
\end{tabular}


Tabela 3

Dopuszczalne emisje substancji toksycznych według Rozporzadzenia Parlamentu Europejskiego i Rady (UE) 2016/1628 z dnia 14 września 2016 r.

\begin{tabular}{|c|c|c|c|c|c|}
\hline Moc & $\begin{array}{c}\text { Data } \\
\text { wprowa- } \\
\text { dzenia }\end{array}$ & $\begin{array}{c}\text { Tlenek } \\
\text { węgla } \\
\text { CO }\end{array}$ & $\begin{array}{c}\text { Węglo- } \\
\text { wodory } \\
\text { HC }\end{array}$ & $\begin{array}{c}\text { Tlenki } \\
\text { azotu } \\
\mathbf{N O}_{\boldsymbol{x}}\end{array}$ & $\begin{array}{c}\text { Cząstki } \\
\text { stale } \\
\mathbf{P M}\end{array}$ \\
\hline$[\mathbf{k W}]$ & - & {$[\mathbf{g} / \mathbf{k W h}]$} & {$[\mathbf{g} / \mathbf{k W h}]$} & {$[\mathbf{g} / \mathbf{k W h}]$} & {$[\mathbf{g} / \mathbf{k W h}]$} \\
\hline \multicolumn{5}{|c|}{ Etap V } \\
\hline $37-56$ & 01.2019 & 5,0 & $\mathrm{NO}_{x}+\mathrm{HC}-4,7$ & 0,015 \\
\hline $56-130$ & 01.2020 & 5,0 & 0,19 & 0,4 & 0,015 \\
\hline $130-560$ & 01.2019 & 3,5 & 0,19 & 0,4 & 0,015 \\
\hline
\end{tabular}

Źródło: opracowano na podstawie danych zawartych w ww. rozporządzeniu

W stosunku do PN-EN 1679-1+A1:2011 obecnie obowiązujące przepisy znacząco zaostrzyły wymagania co do poziomu emisji węglowodorów (HC), a najbardziej co do poziomu emisji tlenków azotu $\left(\mathrm{NO}_{x}\right)$ i cząstek stałych (PM), pozostawiając bardzo zbliżone wartości emisji tlenku węgla $(\mathrm{CO})$. $\mathrm{Z}$ porównania danych zawartych w tabelach 1 i 2 wynika, że silniki spełniające wymagania normy PN-EN 1679-1+A1:2011 odpowiadają silnikom spełniającym wymagania etapu I, według uchylonej dyrektywy spalinowej. Można zatem zauważyć różnice w wymaganiach unijnych. W zakresie jakości emitowanych spalin, nowo wprowadzane do obrotu maszyny mobilne $\mathrm{z}$ napędem spalinowym przeznaczone do stosowania w podziemnych wyrobiskach niezagrożonych wybuchem, jak np. pojazdy oponowe, powinny spełniać wymagania etapu $\mathrm{V}$ podane w tabeli 3. Maszyny mobilne (w tym lokomotywy dołowe do kopalnianej kolei podziemnej), przeznaczone do stosowania $\mathrm{w}$ atmosferach zagrożonych występowaniem metanu i/lub palnego pyłu, winny spełniać wymagania podane w tabeli 4 , odpowiadające wymaganiom etapu IIIA uchylonej dyrektywy spalinowej. Natomiast pozostałe maszyny przeznaczone do pracy pod ziemią, w zakresie emisji spalin, mogą spełniać wymagania podane w tabeli 1 .

Należy także zwrócić uwagę na obowiązujące od 1 lipca 2017 r. Rozporzadzenie Ministra Energii $z$ dnia 23 listopada $2016 r$. w sprawie szczegótowych wymagań dotyczacych prowadzenia ruchu podziemnych zakładów górniczych [7], które w §635 zawiera zapisy:

1. W pojazdach i w maszynach $\mathrm{z}$ napędem spalinowym stosuje się silniki z zapłonem samo-czynnym.

2. Zawartość tlenku węgla w spalinach wyrzucanych przez układ wylotowy silnika, w każdym jego ustalonym stanie pracy, wynosi nie więcej niż:

- 500 ppm - w kopalniach niezagrożonych wybuchem metanu;

- 500 ppm - w kopalniach zagrożonych wybuchem metanu, w przypadku, gdy stężenie metanu w powietrzu zasysanym wynosi $0,0 \%$;

- 1200 ppm - w kopalniach zagrożonych wybuchem metanu, w przypadku, gdy stężenie metanu w powietrzu zasysanym wynosi $1,0 \%$;

- 1800 ppm - w kopalniach zagrożonych wybuchem metanu, w przypadku, gdy stężenie metanu w powietrzu zasysanym wynosi $1,5 \%$.

3. Liczbę pojazdów i maszyn $z$ napędem spalinowym pracujących równocześnie w wyrobisku ustala się w sposób zapewniający nieprzekroczenie dopuszczalnych wartości stężenia szkodliwych gazów w powietrzu, o których mowa w §142 ust. 2 (tj. dwutlenku węgla maks. 1\%, tlenku węgla maks. 0,0026\%, tlenku azotu maks. 0,00026\%, dwutlenku siarki maks. 0,000075\%, siarkowodoru maks. $0,0007 \%$ przy zachowaniu zawartości tlenu $\min .19 \%)$.

\section{Tabela 4}

Dopuszczalne emisje substancji toksycznych według Rozporzadzenia Parlamentu Europejskiego i Rady (UE) 2016/1628 z dnia 14 września 2016 r. dla silników przeznaczonych do montażu w maszynie mobilnej, która ma być użytkowana w atmosferze potencjalnie wybuchowej

\begin{tabular}{|c|c|c|c|c|c|}
\hline Moc & Data wprowadzenia & $\begin{array}{c}\text { Tlenek weggla } \\
\mathbf{C O}\end{array}$ & $\begin{array}{c}\text { Węglowodory } \\
\mathbf{H C}\end{array}$ & $\begin{array}{c}\text { Tlenki azotu } \\
\mathbf{N O}_{\boldsymbol{x}}\end{array}$ & $\begin{array}{c}\text { Cząstki stałe } \\
\mathbf{P M}\end{array}$ \\
\hline$[\mathbf{k W}]$ & - & {$[\mathbf{g} / \mathbf{k W h}]$} & {$[\mathbf{g} / \mathbf{k W h}]$} & {$[\mathbf{g} / \mathbf{k W h}]$} & {$[\mathbf{g} / \mathbf{k W h}]$} \\
\hline $37-56$ & 01.2017 & 5,0 & \multicolumn{2}{|c|}{$\mathrm{NO}_{x}+\mathrm{HC}-4,7$} & 0,4 \\
\hline $56-130$ & 01.2017 & 5,0 & \multicolumn{2}{|c|}{$\mathrm{NO}_{x}+\mathrm{HC}-4,0$} & 0,3 \\
\hline $130-560$ & 01.2017 & 3,5 & \multicolumn{2}{|c|}{$\mathrm{NO}_{x}+\mathrm{HC}-4,0$} & 0,2 \\
\hline
\end{tabular}

Źródło: opracowano na podstawie danych zawartych w ww. rozporządzeniu 
Zauważalne są różnice pomiędzy ww. zapisami a wymaganiami unijnymi (np. brak wymagań w zakresie tlenków azotu, węglowodorów i cząstek stałych), a kryterialnym czynnikiem decydującym o możliwości zastosowania maszyn $\mathrm{z}$ napędem spalinowym $\mathrm{w}$ danym wyrobisku są warunki wentylacyjne. Nie określono wymagań kontrolnych co do napędów spalinowych podczas ich eksploatacji, zakładając, że każdy z producentów określi wymagania co do kontroli (sposób i częstotliwość przeprowadzania, kryteria dalszej eksploatacji) w instrukcji (dokumentacji techniczno-ruchowej).

\section{TECHNICZNE MOŻLIWOŚCI REALIZACJI WYMAGAŃ}

DLA NAPĘDÓW SPALINOWYCH EKSPLOATOWANYCH W WYROBISKACH POTENCJALNIE ZAGROŻONYCH WYBUCHEM

Mając na uwadze spełnienie wymagań tzw. dyrektywy spalinowej, producenci silników opracowali stosowne rozwiązania swoich produktów do zastosowania w maszynach niedrogowych, eksploatowanych na powierzchni. Przykładowe rozwiązania jednego z producentów przedstawiono w tabeli 5 .

Tabela 5

Rozwój rozwiązań silników spalinowych do pojazdów niedrogowych [8]

\begin{tabular}{|c|c|c|}
\hline Etap & Schemat & Opis \\
\hline & towico & $\begin{array}{l}\text { Przedstawiony układ stanowi najprostsze rozwiązanie } \\
\text { ze sterowaną mechanicznie pompą rzędową lub roz- } \\
\text { dzielaczową [9]. Silnik jest wyposażony w dwuza- } \\
\text { worową głowicę, typową turbosprężarkę ze stałą geo- } \\
\text { metrią łopatek kierownicy, prosty układ dolotowy } \\
\text { z filtrem powietrza oraz układ wylotowy. }\end{array}$ \\
\hline II & $\begin{array}{c}\text { głowica dwu- } \\
\text { lub ctzerozaworowa }\end{array}$ & $\begin{array}{l}\text { Rozwinięciem poprzedniego układu jest wyposażenie } \\
\text { silnika w wysokociśnieniowy układ zasilania pali- } \\
\text { wem np. Common Rail [9] sterowany elektronicznie, } \\
\text { dwu- lub czterozaworową głowice oraz chłodnicę } \\
\text { powietrza doładowującego (tzw. intercooler). Silnik } \\
\text { na ogół wyposażony jest w turbosprężarkę o stałej } \\
\text { geometrii łopatek kierownicy. Zastosowanie inter- } \\
\text { coolera pozwoliło zwiększyć moc rozwijaną przez } \\
\text { silnik, natomiast elektroniczne sterowanie procesem } \\
\text { wtrysku spowodowało zmniejszenie poziomu obec- } \\
\text { ności szkodliwych substancji w spalinach. }\end{array}$ \\
\hline IIIA & czterozaworowo & $\begin{array}{l}\text { Kolejnym krokiem było zastosowanie systemu EGR } \\
\text { z własną chłodnicą oraz turbospreżarki ze zmienną } \\
\text { geometrią łopatek kierownicy. Wykorzystanie schło- } \\
\text { dzonej czéści strumienia spalin pozwoliło obniżyć } \\
\text { temperaturę procesu spalania, w efekcie czego ogra- } \\
\text { niczono powstawanie tlenków azotu }\left(\mathrm{NO}_{x}\right) \text {. Zastoso- } \\
\text { wanie turbosprężarki o zmiennej geometrii łopatek } \\
\text { kierownicy pozwoliło na polepszenie charakterystyk } \\
\text { pracy silnika (np. zmniejszenie efektu tzw. turbo- } \\
\text { dziury przy niskiej prędkości wylotowej spalin). }\end{array}$ \\
\hline
\end{tabular}


Tabela $5 \mathrm{~cd}$.

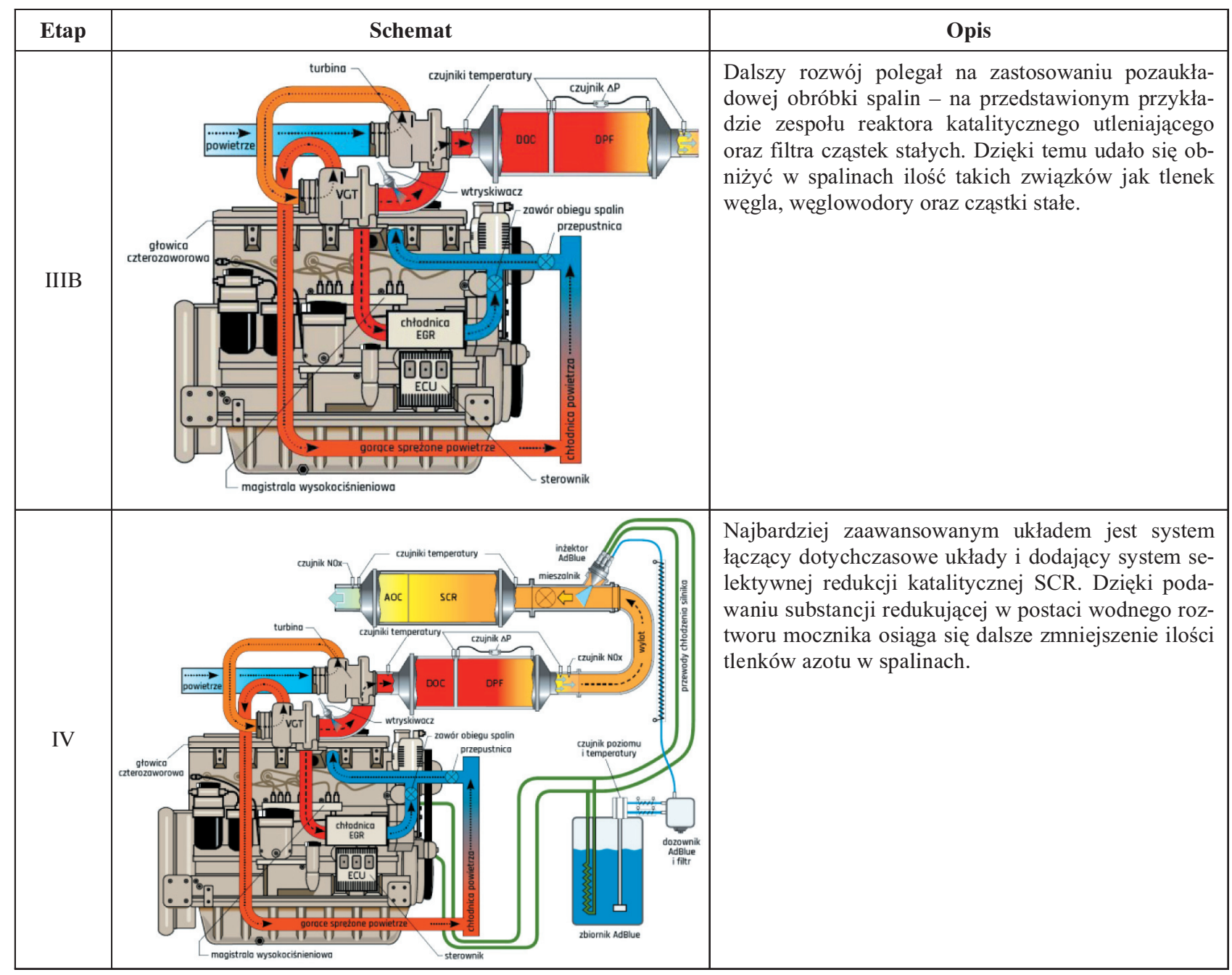

Na podstawie informacji zawartych w tabeli 5 można stwierdzić, że:

- wymagana jakość spalin w etapie I, II oraz IIIA została osiągnięta dzięki doskonaleniu układu zasilania silnika, w szczególności zaś sterowania czasem i liczbą faz wtrysku paliwa;

- poziom emisji poszczególnych substancji zgodnie z wymaganiami etapu IIIB oraz IV może być spełniony jedynie przy użyciu tzw. pozaukładowej obróbki spalin, składającej się m.in. z reaktorów katalitycznych, filtra cząstek stałych oraz innych.

Należy nadmienić, że żaden z producentów silników spalinowych nie produkuje ani nie przystosowuje wytwarzanych silników do eksploatacji w podziemnych wyrobiskach zagrożonych wybuchem metanu i/lub palnego pyłu, pozostawiając rozwiązanie tego problemu producentowi dołowej maszyny z napędem spalinowym.

Na rysunku 2 przestawiono przykładowe, przeciwwybuchowe rozwiązanie spalinowego układu napędo- wego do urządzeń transportowych eksploatowanych w podziemnych wyrobiskach zagrożonych wybuchem metanu i/lub palnego pyłu.

Silnik wyposażono w chłodzone cieczą ( $\mathrm{z}$ obiegu silnika): kolektor wylotowy spalin oraz turbo-sprężarkę, a także płaszcz przewodu wylotu spalin. W miejsce wodnej płuczki spalin może być stosowany „suchy” wymiennik ciepła. Wodna płuczka spalin, w której spaliny przepływają przez poszczególne komory, bezpośrednio kontaktując się z wodą, pozwala na schłodzenie spalin oraz wymywanie sadzy. Wymagana jest okresowa wymiana wody (po każdej zmianie roboczej). Niekorzystnym zjawiskiem jest odparowywanie wody, a także zdarzające się jej wychlapywanie podczas eksploatacji. W ,suchym” wymienniku ciepła nie dochodzi do bezpośredniego kontaktu spalin z chłodzącą je wodą, w wyniku czego spaliny nie są oczyszczane z sadzy. Wymagany jest dodatkowy układ chłodzenia wody (pompa, chłodnica). Instaluje się elektroniczne systemy nadzoru, kontrolujące 
parametry decydujące o bezpieczeństwie pracy. $\mathrm{Na}$ rysunku 3 przedstawiono przykładowe rozwiązanie silnika spalinowego spełniającego wymagania etapu I fabrycznie wyposażonego w chłodzone cieczą: turbinę i kolektor wylotowy spalin.

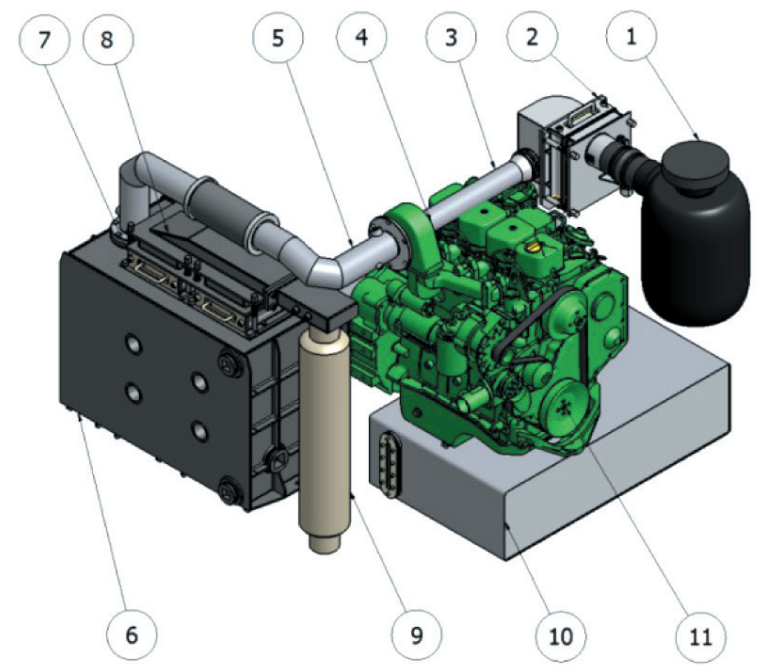

Rys. 2. Przykładowe rozwiazanie zespołu silnika przeznaczonego do pracy $w$ przestrzeniach zagrożonych wybuchem metanu i/lub pyłu weglowego, spetniajacego wymagania etapu I/II: 1 - filtr powietrza, 2 - dolotowy przerywacz ptomieni, 3 - przewód dolotowy, 4 - turbosprężarka, 5 - przewód wylotu spalin, 6-wodna płuczka spalin, 7 - wylotowy przerywacz ptomieni, 8 - kolektor zbiorczy układu wylotowego, 9 - iskrochron, 10 - zbiornik paliwa, 11 - silnik spalinowy [5]

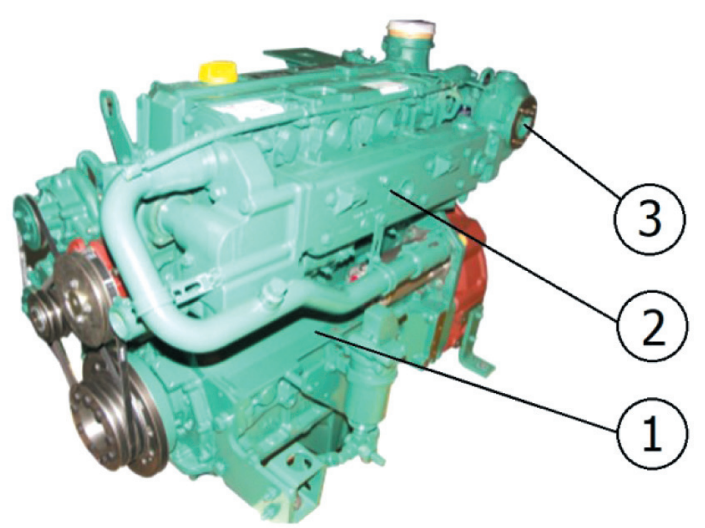

Rys. 3. Przyktadowe rozwiazanie zespotu silnika przeznaczonego do pracy $w$ przestrzeniach zagrożonych wybuchem metanu i/lub pyłu weglowego, spetniajacego wymagania etapu I/II: 1 - silnik spalinowy, 2 - chtodzony ciecza kolektor wylotowy spalin, 3 - chtodzona ciecza turbosprężarka [5]

Silniki spalinowe, stosowane dotychczas przez krajowych producentów urządzeń transportowych, eksploatowanych w podziemnych wyrobiskach zagrożo- nych wybuchem metanu i/lub palnego pyłu, spełniają wymagania dyrektywy spalinowej w zakresie etapu II, a w incydentalnych przypadkach etapu IIIA. Zastosowanie silników spełniających aktualne wymagania niesie za sobą konieczność podjęcia prac badawczorozwojowych. Posiadane zasoby: doświadczeni specjaliści dysponujący odpowiednią wiedzą oraz stanowisko badawcze umożliwiają podjęcie tych prac przez Instytut KOMAG. Na rysunku 4 przedstawiono przykładowe przemysłowe rozwiązanie silnika spalinowego spełniającego wymagania etapu IV/V.

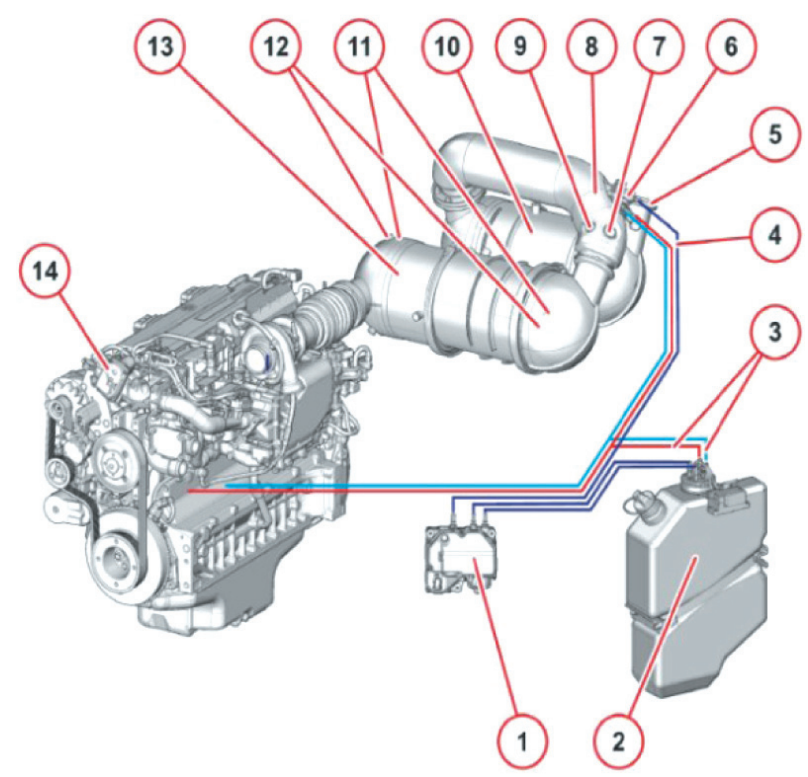

Rys. 4. Przykładowe przemystowe rozwiazanie silnika spalinowego spetniajacego wymagania etapu $I V / V$ : 1 - pompa SCR, 2 - zbiornik SCR, 3 - przewód płynu chtodniczego do wstępnego podgrzewania zbiornika SCR do chtodzenia dozownika, 4 - przewód SCR, 5 - czujnik $N O_{x} 6$-dozownik, 7 - czujnik $N O_{x}, 8$-czujnik temperatury, 9 - czujnik ciśnienia, 10 - reaktor katalityczny SCR, 11 - czujnik ciśnienia różnicowego, 12 - czujnik temperatury, 13 - filtr czastek statych (DPF) do silników diesla, 14 - przepustnica [10]

Dostosowanie silnika do pracy w przestrzeniach zagrożonych wybuchem metanu i/lub pyłu węglowego zgodnie z wymaganiami dyrektywy ATEX oraz dyrektywy spalinowej obejmuje [11]:

- zabezpieczenie temperaturowe powierzchni kolektora wylotowego i turbosprężarki,

- zabezpieczenie przeciwwybuchowe układu dolotowo-wylotowego przerywaczami płomienia,

- zabezpieczenie przeciwwybuchowe wyposażenia elektrycznego silnika - wtryskiwaczy, czujników, sterownika silnika, alternatora oraz rozrusznika. 
Dostosowanie fabrycznego silnika, spełniającego wymagania poziomu etapu IIIA, umożliwiającego zaprojektowanie napędu spalinowego do przestrzeni zagrożonych wybuchem metanu i/lub pyłu węglowego, wymaga podjęcia prac badawczo-rozwojowych związanych z opracowaniem:

- kolektora wylotowego spalin oraz turbosprężarki w wersji przeciwwybuchowej (ognioszczelnej) chłodzonych wodą,

- adaptacji istniejącego układu sterowania (sterownik, czujniki) do warunków przeciw-wybuchowych.

Zasadniczą kwestią pozostaje dostosowanie wtryskiwaczy do pracy w atmosferze zagrożonej wybuchem. Z uwagi na konieczność dokładnego pozycjonowania wtryskiwaczy w gniazdach, ich stabilnego zamocowania oraz wysoką temperaturę pracy, przystosowanie ich do wymagań dyrektywy ATEX jest złożonym zagadnieniem technicznym. Niezbędna będzie zatem ścisła współpraca z dostawca silnika.

\section{PODSUMOWANIE}

Transport materiałów i urobku oraz przewóz ludzi jest jednym z najważniejszych ogniw procesu wydobywczego zakładu górniczego. W miejsce szeroko stosowanych urządzeń transportowych $\mathrm{z}$ napędem linowym, z uwagi na ich ograniczenia, od 1990 roku w podziemiach kopalń węgla kamiennego coraz szerzej stosowane są kolejki z napędem spalinowym. Powstała infrastruktura (zajezdnie, komory tankowania paliw) stanowiła przyczynek do zastosowania lokomotyw spalinowych w kopalnianych kolejach podziemnych. Zastosowane napędy spalinowe powinny spełniać wymagania dotyczące ich bezpiecznej eksploatacji w wyrobiskach zagrożonych wybuchem, a także unijne wymagania co do jakości spalin. Wykazano różnice co do tych wymagań. Z norm zharmonizowanych z dyrektywą maszynową wynika, że wozy oponowe, a także maszyny mobilne (w tym lokomotywy dołowe do kopalnianej kolei podziemnej), przeznaczone do stosowania w atmosferach zagrożonych występowaniem metanu i/lub palnego pyłu muszą spełniać znacznie ostrzejsze wymagania Rozporządzenia Parlamentu Europejskiego i Rady (UE) 2016/1628 z dnia 14 września 2016 roku (tj. etapy V i IIIA), od pozostałych maszyn wymagajacych spełnienia zapisów PN-EN 1679-1+A1:2011.
Producenci silników oferują rozwiązania spełniające wymagania emisji spalin etapu $\mathrm{V}$ dla pojazdów niedrogowych, natomiast nie mają w ofercie silników do maszyn mobilnych, przeznaczonych do stosowania w atmosferach zagrożonych występowaniem metanu i/lub palnego pyłu. W celu ich dostosowania do wymagań dyrektywy ATEX niezbędne jest podjęcie prac badawczo-rozwojowych obejmujących:

- zabezpieczenie temperaturowe powierzchni kolektora wylotowego i turbosprężarki,

- zabezpieczenie przeciwwybuchowe układu dolotowo-wylotowego przerywaczami płomienia,

- zabezpieczenie przeciwwybuchowe wyposażenia elektrycznego silnika - wtryskiwaczy, czujników, sterownika silnika, alternatora oraz rozrusznika.

Wyżej wymienionych prac może podjąć się Instytut KOMAG w ścisłej współpracy z producentem silnika.

\section{Literatura}

[1] Ustawa z dnia 15 kwietnia 2016r. o systemach oceny zgodności i nadzoru rynku, Dz.U. 2016, poz. 542 z późn. zm.

[2] Ustawa z dnia 9 czerwca 2011 r. - Prawo geologiczne i górnicze, Dz.U. 2011 nr 163, poz. 981 z późn. zm., tekst jednolity Dz.U. 2017, poz. 2126, stan prawny na 12.10 .2017 r.

[3] Rozporządzenie Rady Ministrów z dnia 30 kwietnia $2004 r$ $w$ sprawie dopuszczania wyrobów do stosowania $w$ zakładach górniczych, Dz.U. 2004, nr 99, poz. 1003 z późn. zm.

[4] Brzeżański M., Pieczora E., Kaczmarczyk K.: Rozwiązania napędów spalinowych do zastosowań $w$ wyrobiskach podziemnych węla kamiennego, „Silniki Spalinowe” 2010, 3: 28-40.

[5] Dobrzaniecki P., Majewski M., Kaczmarczyk K., Suffner H.: Nowoczesny napęd spalinowy maszyn samobieżnych dla górnictwa. Identyfikacja zagadnień $i$ zakresu prac zwiąanych $z$ dostosowaniem silnika spalinowego do wymagań Etapu IV dyrektywy spalinowej, ITG KOMAG, Gliwice 2016 [praca niepublikowana].

[6] Pieczora E., Suffner H.: Rozwój napędów dołowych kolejek podwieszonych, „Maszyny Górnicze” 2017, 3: 44-57.

[7] Rozporzadzenie Ministra Energii z dnia 23 listopada $2016 r$ $w$ sprawie szczegółowych wymagań dotyczacych prowadzenia ruchu podziemnych zakładów górniczych, Dz.U. 2017, poz. 1118.

[8] Materiały firmy John Deere, www.deere.pl, 2017.

[9] Dobrzaniecki P., Kaczmarczyk K.: Układy zasilania silników spalinowych eksploatowanych $w$ kopalniach węgla kamiennego na przykładzie rozwiąań ITG KOMAG, ,Maszyny Górnicze" 2017, 1: 63-76.

[10] Dobrzaniecki P.: Dostosowanie silnika spalinowego z układem wtryskowym common rail górniczej maszyny roboczej do obowiązujących wymagań i przepisów, „Maszyny Górnicze” 2016, 3: 45-53.

[11] Materiaty firmy Deutz [udostepnione przez Biuro Techniczno-Handlowe FAST], 2017.

dr inż. EDWARD PIECZORA dr inż. PIOTR DOBRZANIECKI Instytut Techniki Górniczej KOMAG ul. Pszczyńska 37, 44-101 Gliwice \{epieczora, pdobrzaniecki\}@komag.eu 